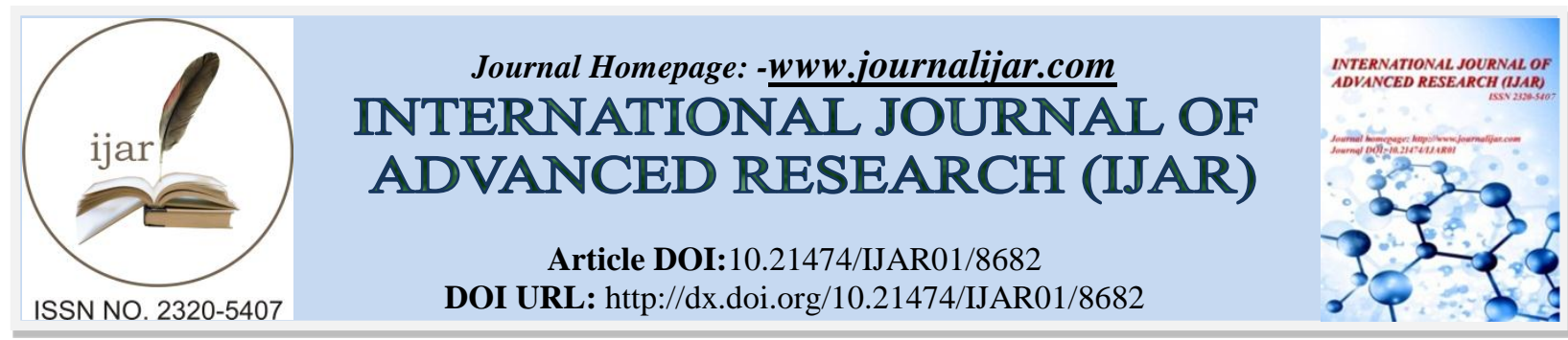

RESEARCH ARTICLE

\title{
INFLUENCE OF LIGNEOUS PLANTS ON THE FEEDING BEHAVIOR OF ZEBU GOBRA IN THE AGROPASTORAL AREA OF THE GROUNDNUT BASIN.
}

Mamadou Bocar Thiam ${ }^{1}$, Saliou Ngom ${ }^{1}$, Coly Wade ${ }^{2}$, Moussa Camara ${ }^{1}$ and Abdoulaye Dieng ${ }^{2}$.

1. Senegalese Institute of Agricultural Research, PO Box 3120, Dakar, Senegal.

2. University of Thies BP 967 A - Thies, Senegal.

\section{Manuscript Info}

Manuscript History

Received: 13 January 2019

Final Accepted: 15 February 2019

Published: March 2019

Key words:-

pastoralism, woody fodder, food value, Senegal.

\section{Abstract}

An experimental study on the feeding behavior of cattle in the real world was conducted in an agro-pastoral farm practicing the extensive system associating cultivation of millet and the management of cattle on a natural range. Do they go together even if the farm practices the extensive system? The collection and sorting done on the diet allowed to determine its composition as well as the influence of the seasons on the variation of the diet. It has been shown that this diet consists mainly of spontaneous grasses (gramineous, leguminous), millet straw, ligneous and plant debris. The average daily intake is $4.87 \pm 0.96 \mathrm{~kg}$ DM per UBT (Tropical Livestock Unit). In addition, the presence of woody foods in the diet is a factor in maintaining their intake at an acceptable level despite the decrease in herbaceous resources. In fact, there is a positive correlation between the quantity ingested and the rate of incorporation of ligneous plants in the diet $r=0.38$ ( $p$-value <0.001) despite the winter season when the absence of ligneous plants in the cattle diet is justified by the abundance of more accessible green herbs. Finally, chemical analyses showed the nutritional values of some of the most appetized woody species in the area.

Copy Right, IJAR, 2019,. All rights reserved.

\section{Introduction:-}

Livestock have always contributed significantly to a key role in the valorization of plant biomass on farms and in the production of organic manure (Blanchard, 2010). Extensive breeding plays a key role in the valorization of pastoral areas but also in the organic fertilization of crop plots. However, the maintenance of the animals can be confronted with the deficit of food resources especially in case of low rainfall. In order to cope with a possible deficit and ensure a good diet, the herds exploit a variety of plant resources ranging from herbaceous plants to woody plants and crop residues. The choice of these resources is guided by a number of factors including the season.

In effect, in dry season, the forage production herbaceous is low and of lesser quality. It loses its nutritional value and becomes rare. While a forage woody remains alive during the unfavorable season and allows to feed the cattle during the dry season (Traoré 2016; Traoré, 1998).

Force is to note that nearly 80 per cent of the Senegalese herd is fed on natural pasture and that the Biomass pâturable woody origin reached the $35 \%$ (Breman, 1995) and that their significant concentration in contents total nitrogenous can reach 35\% (Riviere, 1978, ; Kearl, 1982). 
In the Sahelian zone, ligneous trees play a special role in the diet, especially during the dry season.

More than $75 \%$ of West African trees and shrubs (Sarr et al 2013) would help meet the nitrogen needs of ruminants and improve the nutritional status of livestock in traditional, extensive and semi-intensive livestock breeding (Bognounou, 2004).

The purpose of this paper is to determine the role of ligneous plants in the feeding behavior of gobra cattle on pastoral routes.

\section{Material And Methods:-}

\section{Presentation of the study area}

The case study focuses on the Sereers agrarian systems in the heart of the groundnut basin of Senegal, a particularly dynamic agricultural zone, with a high and increasing demographic pressure, illustrating the dynamics that could be observed in the next decades in west Africa. Experimental trials were conducted in the village of Diohine (Figure 1) in Fatick area. The climate is Sudano-Sahelian with rainfall ranging between 400 and $600 \mathrm{~mm}$ spread over 3 months of rain. The agricultural system is generally characterized by rainfed cultivation (groundnuts, millet, sorghum, cowpeas, etc.) and domestic ruminant farming. A traditional farming system is practiced, based on collective fallows, free grazing and nocturnal parching of animals in future culivate land.

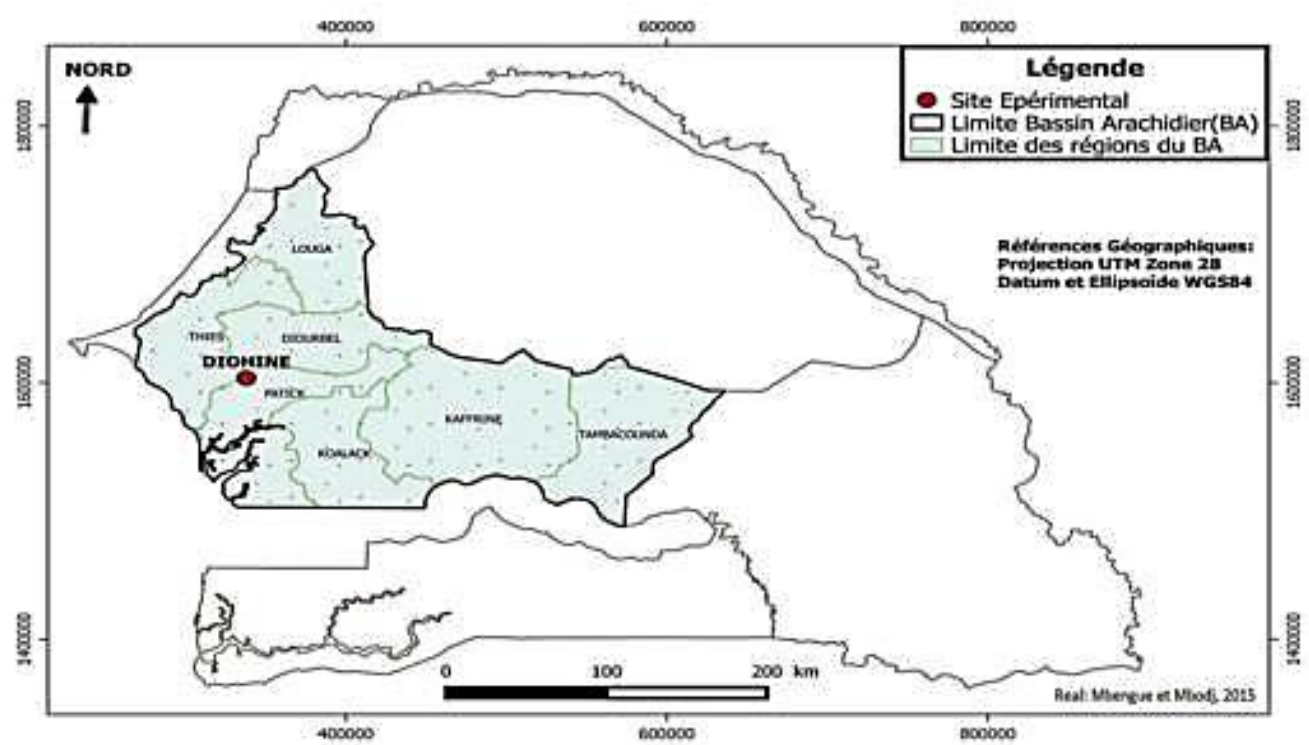

Figure 1:-Location of the village of Diohine in Senegal (Mbengue and Mbodji, 2015)

\section{Collection and processing of data}

Follow-up of 4 animals were monitored during one year in 2 farms in real environment. The collection of the shepherd (Guérin et al., 1984) is a method that consists of following the animal on pasture (Figure 2) and reconstituting his food bowl by mimicking his mouthfuls by hand. It was used to collect, quantify and sort the diet of cattle to determine their floristic and chemical composition. The sorting of plant biomass was done in four types of forage resources: millet straw, ligneous, herbaceous and debris. This sorted biomass (raw material) was then converted to dry matter after drying in an oven ( $60^{\circ}$ for 48 hours after obtaining a constant weight). 


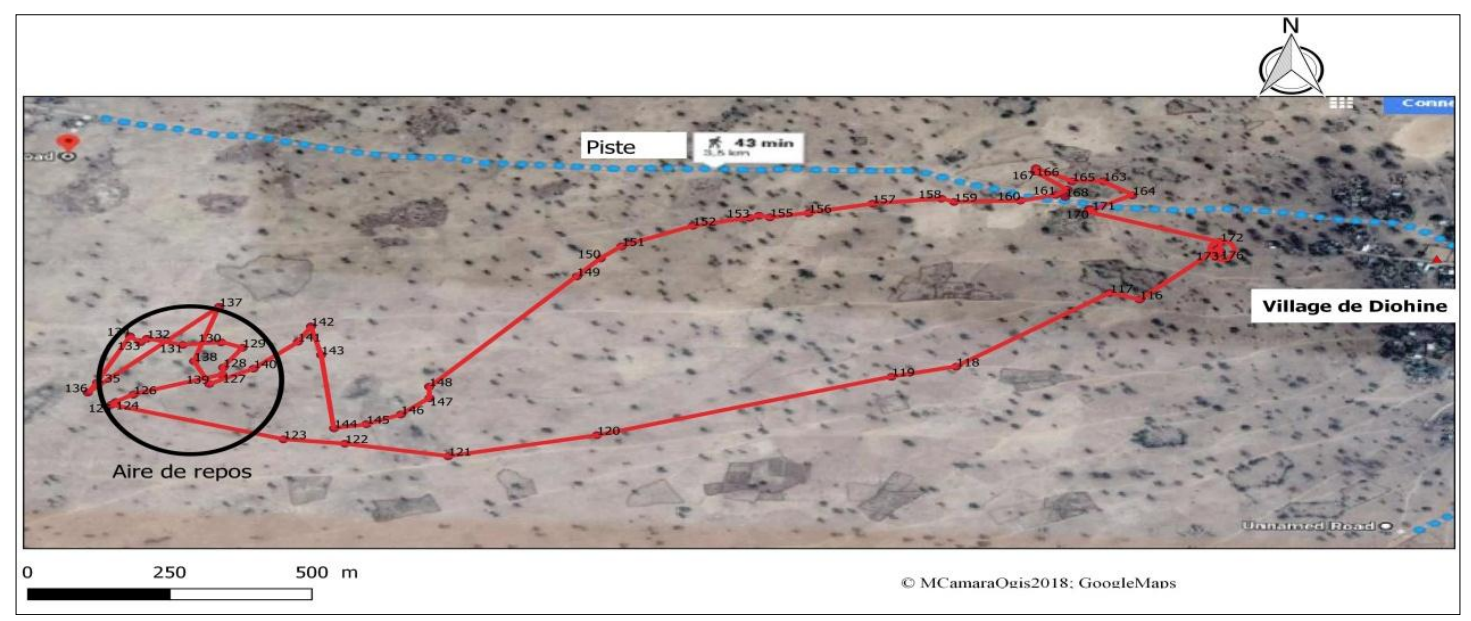

Figure 2:-Journey of a herd of Diohin cattle in the Senegalese groundnut basin (Fatick)

The samples obtained were analyzed at the National Laboratory for Livestock and Veterinary Research in Hann (Dakar) in order to determine their chemical composition and nutritional value. To overcome the weight variations between animals, they were converted into a tropical livestock unit (UBT) which is a theoretical reference animal. This unit was determined using live weight obtained by regular weighing and barometric measurements. The formula developed at the National Laboratory for Livestock and Veterinary Research (LNERV) determined the live weight and its equivalent UBT. It is based on barymetric measurements including the thoracic perimeter:

$$
\mathrm{PV}=0,0247 \mathrm{PPT}^{2}-2,543 \times \mathrm{PT}+83,917
$$

At the same time, a survey was conducted among breeders to understand the practices linked to the exploitation of ligneous species in extensive breeding. The data was organized using the Excel 2013 workbook and processed using the statistical analysis software R, in particular for the normality and linear regression tests.

\section{Results:-}

The variation in the composition and quantity of the diet of the animals on the route is largely dependent on the grazing period (Table1). Three main periods were identified: the cold dry season (SSF: from November to February), the hot dry season (SSC: from March to June) and the winter season (SH: from July to October). During the entire year, the diet is mainly herbaceous (41\%), woody (34\%), millet straw (21\%) and debris (3\%). The average annual intake is $4.87 \pm 0.96 \mathrm{Kg} . \mathrm{MS} / \mathrm{UBT} / \mathrm{day}$. In relation to the seasons, it increases to $4.15 \pm 0.9 \mathrm{Kg} . \mathrm{MS} / \mathrm{UBT} / \mathrm{day}$ in SSF, $5.16 \pm 0.7 \mathrm{Kg} . \mathrm{MS} / \mathrm{UBT} /$ day in SSC and $5.3 \pm 1 \mathrm{Kg} . \mathrm{MS} / \mathrm{UBT} /$ day in SH.

Table 1:-Composition and variation of the diet according to the season in $\mathrm{kg}$ of DM / UBT / day

\begin{tabular}{|l|r|r|r|r|r|r|}
\hline Month & \multicolumn{1}{|c|}{ Ingested } & \multicolumn{1}{|c|}{ Straws } & \multicolumn{1}{l|}{ Herbaceous } & \multicolumn{1}{l|}{ ligneous } & \% ligneous \\
\hline March & 5.04 & 0.99 & 1.04 & 0.75 & 2.26 & 45 \\
\hline April & 6.06 & 0.39 & 0.29 & 0.12 & 5.26 & 87 \\
\hline May & 5.21 & 1.35 & 0.19 & 0.39 & 3.28 & 63 \\
\hline June & 4.32 & 1.63 & 0.13 & 0.10 & 2.46 & 57 \\
\hline July & 5.01 & 0.08 & 0.75 & 0 & 4.18 & 83 \\
\hline August & 5.95 & 0 & 5.95 & 0 & 0 & 0 \\
\hline September & 6.22 & 0 & 6.22 & 0 & 0 & 0 \\
\hline October & 3.99 & 0 & 3.99 & 0 & 0 & 0 \\
\hline November & 3.42 & 1.17 & 2.25 & 0 & 0 & 0 \\
\hline December & 3.27 & 1.88 & 1.39 & 0 & 0 & 0 \\
\hline January & 5.10 & 2.50 & 1.20 & 0 & 1.40 & 27 \\
\hline February & 4.80 & 1.50 & 1.00 & 0.50 & 1.80 & 38 \\
\hline
\end{tabular}

There is correlation between the total amount ingested and the proportion of tree present in the diet (Figure 3). Indeed the linear regression reveals a coefficient $r=0.38$ ( $\mathrm{p}$-value $<0.001)$. The Shapiro-Wilk normality test 
confirmed the initial conditions with a p-value of 0.60, contrary to that of Breusch-Pagan and Durbin-Watson, which gave p-values of 0.02 and 0.07 .

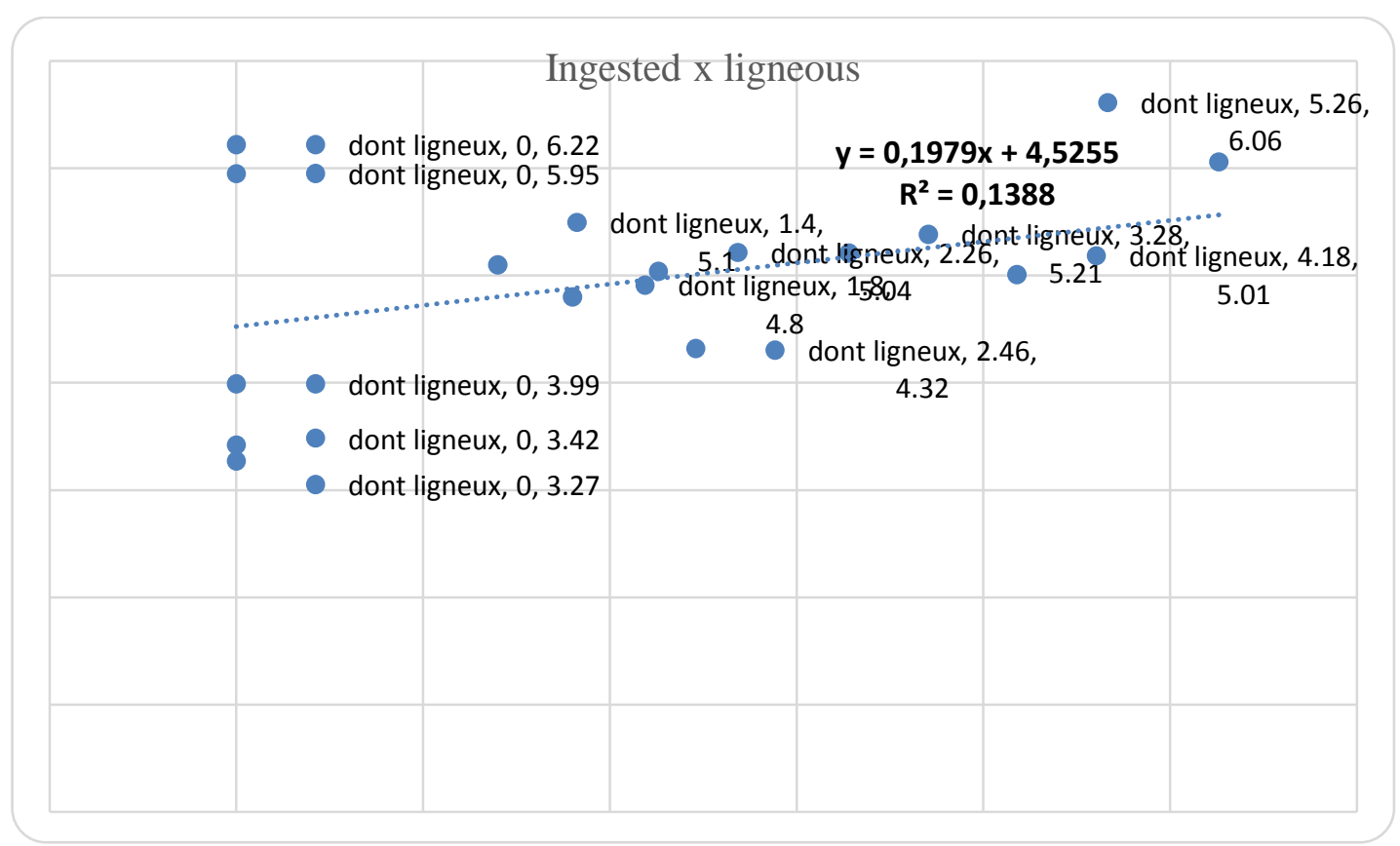

Figure 3:-Point Cloud and Linear Regression Between Ingested and Woody Share

Among the periods when there is an absence of ligneous in the diet, we note that the months of August and September have above average intake. This is justified by the abundance of green grasses linked to the rainy season. Nevertheless, the ligneous allow the maintenance of the level of ingestion in particular during period of rarefaction of the grass resources. In total, 28 species of ligneous were identified, of which 23 considered as fodder ligneous or $82.14 \%$ (Table 2). Of the $82.14 \%$ of species inventoried as fodder, $43.47 \%$ are very palatable, $17.39 \%$ are palatable and 39.13 are less palatable

Table 2:-Some woody appetites from grazing animals

\begin{tabular}{|l|l|l|}
\hline Highly palatable species & Appetized species & Poorly appetized species \\
\hline Faidherbia albida, & Heeria insignis, & Borassus aethiopum, Stereospermum \\
Balanites aegyptiaca, Adansonia & Piliostigma reticulatum, & kunthianum, Cassia sieberiana, \\
digitata, Tamarindus indica, & Terminalia avicennioides & Diospyros mespiliformis, \\
Guiera senegalensis, Terminalia & Acacia seyal. & Dichrostachys cinera. \\
macroptera, Prosopis africana, & & \\
Ficus capensis, & & \\
Ziziphus mauritiana Sterculia & & \\
setigera & & \\
\hline
\end{tabular}

For access arrangements, ruminants have access to aerial forage through controlled grazing, free grazing, pruning and shaking or harvesting. Cattle are grazed directly or by pruning. Shepherds then climb to make available to the cattle herd the leafy twigs of fodder trees as soon as the height of the woody is greater than two meters. They shake the branches of the ligneous by means of sticks or sticks in order to make the inaccessible fruits available to the cattle. By means of these modalities, different parts of the ligneous are consumed by the farm animals.

Table 3:-Operated Parties and Proportion of Livestock Operators by Livestock Producers

\begin{tabular}{|l|c|c|c|c|}
\hline \multirow{2}{*}{ Species } & \multicolumn{3}{|c|}{ Parties exploited and proportions in\% } \\
\cline { 2 - 5 } & Leaves & Fruits & Flowers & boughs \\
\hline Adansonia digitata L. & 100 & 0 & 0 & 0 \\
\hline Cordyla pinnata (Lepr. ex A. Rich.) Milne-Redh. & 70 & 0 & 0 & 89 \\
\hline
\end{tabular}




\begin{tabular}{|l|c|c|c|c|}
\hline Faidherbia albida Del. & 76 & 100 & 0 & 100 \\
\hline Ficus capensis Thunb. & 80 & 100 & 0 & 0 \\
\hline Ziziphus mauritiana Lam. & 89 & 94 & 0 & 50 \\
\hline Sterculia setigera Del. & 67 & 88 & 0 & 71 \\
\hline
\end{tabular}

The exploited parts vary from one plant species to another. Leaves with fruits and twigs are the most common parts used by ruminants (Table 3). However, the fruits of Adansonia digitata and Cordyla pinnata are not eaten by livestock. The branches of Adansonia digita and Ficus capensis are also not consumed. This can be explained by the fact that Adansonia digitata and Ficus capensis are very large trees so their branches are rigid for consumption by livestock. Some species contribute to the feeding of ruminants through leaves, fruits and twigs. These are Faidherbia albida, Ziziphus mauritiana and Sterculia setigera. The leaves are the most consumed parts of woody plants. On the other hand, flowers are not consumed by animals. Les ligneux fourragers sont beaucoup plus exploitées à une période où la question de ressources alimentaires naturelles devient critique. A cet effet, les éleveurs ont affirmé exploiter en saison sèche tous les 6 ligneux fourragers pendant les conduites de bovins au pâturage. L'apport à la maison concerne $33 \%$ des éleveurs enquetés. Cette pratique est appliquée aussi bien en saison sèche qu'en saison des pluies. Cependant, ces éleveurs n'ont aucune idée sur les quantités distribuées aux animaux. Ils affirment qu'en saison sèche toutes les 6 principales espèces ligneuses sont concernées par cet apport, contrairement à la saison des pluies où seulement 2 des principales ligneux sont apportés à la maison, en l'occurrence Adansonia digitata et Sterculia setigera pour nourrir surtout les petits ruminants. Woody forage is much more exploited at a time when the issue of natural food resources becomes critical. For this purpose, the breeders stated that during the dry season, all 6 fodder trees were exploited during cattle grazing. The contribution to the house concerns $33 \%$ of the breeders surveyed. This practice is applied both in the dry season and in the rainy season. However, these breeders have no idea about the quantities distributed to the animals. They claim that in the dry season all 6 main ligneous species are concerned by this contribution, contrary to the rainy season where only 2 of the main ligneous are brought to the house, in this case Adansonia digitata and Sterculia setigera to feed especially the small ruminants.

\section{Nutritional value of ligneous}

In addition to helping to maintain the ingestion capacity at an acceptable level during difficult seasons, ligneous trees have a significant nutritional value that can also contribute to achieving the objectives of animal production (maintenance, milk, meat, work ...). Thus, the chemical analyzes (Table 4) revealed variable contents according to the species.

Table 4:-Chemical composition of the woody plants analyzed

\begin{tabular}{|l|c|c|c|c|c|c|c|c|c|c|}
\hline Species & MS & MAT & MG & CB & NDF & ADF & ADL & MM & Ca & P \\
\hline Federbia albida & 72.09 & 13.07 & 3.83 & 20.04 & 43.71 & 36,61 & 18.14 & 8.90 & 0.55 & 0.11 \\
\hline Acacia raddiana & 93.33 & 11.31 & 0.73 & 28.80 & 52.85 & 46,89 & 22.40 & 6.00 & 0.63 & 0.12 \\
\hline Acacia seyal & 92.13 & 6.16 & 1.20 & 39.90 & 59.54 & 48,02 & 12.56 & 6.90 & 0.62 & 0.19 \\
\hline Balanites aegyptiaca & 87.92 & 11.39 & 1.60 & 35.85 & 54.55 & 46,48 & 12.59 & 8.50 & 0.42 & 0.17 \\
\hline Ziziphus mauritiana & 90.40 & 9.59 & 5.53 & 20.60 & 45.62 & 37,94 & 11.51 & 9.23 & 0.68 & 0.13 \\
\hline Boscia senegalensis & 92.09 & 4.35 & 140 & 26.45 & 58.98 & 34,07 & 20.87 & 9.96 & 0.10 & 0.09 \\
\hline Sterculia setigera & 91.78 & 11.83 & 1.14 & 23.17 & 49.65 & 34,68 & 13.35 & 13.99 & 0.11 & 0.20 \\
\hline Combretum micratum & 90.10 & 10.12 & 1.76 & 26.59 & 60.86 & 37,95 & 23.13 & 8.56 & 1.18 & 0.83 \\
\hline
\end{tabular}

$\mathrm{MS}=$ dry matter; MAT = total nitrogenous matter; $\mathrm{MG}=$ fat; $\mathrm{CB}=$ crude cellulose; $\mathrm{NDF}=$ Total walls; $\mathrm{ADF}=$ lignocellulose; $\mathrm{ADL}=$ lignin $; \mathrm{MM}=$ mineral matter $\mathrm{Ca}=$ Calcium $; \mathrm{P}=$ Phosphorus

The results obtained on the biomass composition of ligneous plants used in animal feeds showed an interesting dietary value, compared to herbaceous forage. MAT levels vary significantly depending on the species. The average maximum level is observed in Federbia albida (13.07\% MS) and Sterculia setigera (11.83\% MS higher than that of peanut straw which is the reference food for breeders.

A.raddiana, B. aegyptiaca, Combretum micratum and Z. mauritiana gave average protein contents of 11.31, 11.39, 10.12 and $9.5 \%$ MS, respectively. Total wall contents (NDF) vary significantly depending on the species. The lowest levels were found in Federbia albida with 43.71\% DM. 
Combretum micratum, Acacia raddiana and Boscia senegalensis showed much higher levels of lignin that could limit their incorporation into livestock feed rations (23.13, 22.40 and $20.87 \%$ DM, respectively).

The levels of lignocellulose (ADF) vary very significantly depending on the woody species. The lowest mean grade was observed in Sterculia setigera (34.07) followed by Federbia albida (36.61\% DM). The contents of cellulose (CB) also vary according to the species. The highest average grade was recorded in Acacia seyal with $39.91 \%$ DM, while Federbia albida had a mean minimum value of $20.66 \%$ DM.

Table 5: Food value of the studied species

\begin{tabular}{|l|c|c|c|}
\hline Espèces & UFL & UFV & MAD \\
\hline Acacia albida & 0.59 & 0.48 & 10.26 \\
\hline Acacia raddiana & 0.40 & 0.25 & 8.50 \\
\hline Acacia seyal & 0.56 & 0.46 & 3.35 \\
\hline Balanites aegyptiaca & 0.58 & 0.47 & 8.58 \\
\hline Ziziphus mauritiana & 0.76 & 0.71 & 6.78 \\
\hline Boscia senegalensis & 0.51 & 0.37 & 1.15 \\
\hline Sterculia setigera & 0.72 & 0.75 & 7.95 \\
\hline Combretum micratum & 0.48 & 0.56 & 6.40 \\
\hline
\end{tabular}

The nutritional value calculated from bromatological results revealed a huge food potential for the fodder trees analyzed (Table 5). Of the eight (8) species studied, Ziziphus mauritiana had the highest nutritional value with 0.76 UFL / kg DM, 0.71 UFV / kg DM and 6.78 MAD followed by Sterculia setigera $(0.72 \mathrm{UFL} / \mathrm{kg}$ DM $0.75 \mathrm{UFV} / \mathrm{kg}$ DM, 7.95 MAD). On the other hand, Acacia raddiana showed the lowest food value with 0.40 UFL / kg DM, 0.25 UFV / kg DM and 8.50 g MAD. Federbia albida, Acacia seyal and B. aegyptiaca gave almost similar dietary values. These results showed that the optimal valuation of woody plants could reduce the food deficit during periods when herbaceous forage is rare in rangelands.

\section{Discussion:-}

The proportions constituting the diet of cattle on the range are comparable with the results of Guerin et al. (1987) indicating proportions of herbaceous plants (grasses or legumes) in the diet ranging from 40 to $80 \%$ on natural rangelands. According to Guerin et al. (1984), woody plants can occupy about $30 \%$ of the cattle ration. Due to the seasonal variability in forage availability in the study area, the intake level is higher in the winter season and then in the hot dry season. This would be related to the stage of maximum productivity of the herbaceous carpet between August and September (corresponding to the wet season) and the abundance of woody in the diet especially in April (hot dry season). Hence the determining role of woody forage in maintaining the level of ingestion. However, this ingestion falls at the end of the dry season to stabilize at a low level of about $4.2 \mathrm{Kg}$.DM/UBT/day. In the cold dry season, full period of cheap grazing (December and January), the level of ingestion is even lower (about $4.15 \pm 0.9$ Kg.DM/UBT/day). In this period, crop residues (millet straw in particular) are the main forage resource available for scavenging animals. Under the effect of the high animal load observed in this zone, the animals fail to adequately meet their food needs. These data are in agreement with other studies carried out in the Sahelian regions (5.8 Kg.DM/UBT/day in dry season for Azawak zebu in Niger according to Ayantunde et al (2001), from 5 to $4.5 \mathrm{Kg}$ .DM / UBT / day for Gobra zebu in northern Senegal, at the end of the SS after Molénat et al (2003), around 5 Kg.DM/UBT/day for cattle in Senegal according to Diop and al (2005). In addition, a study conducted by Ickowicz et al (1999) shows that maximum intake was recorded in the rainy season and in the cold dry season, the minima at the end of the dry season. This corroborates the results presented in this study. In an extensive system, stray animals have an annual ingestion that just covers their maintenance needs, often below the standard of $2.5 \mathrm{~kg}$ MS per $100 \mathrm{~kg}$ live weight that defines a tropical livestock unit. This leads to fairly low annual weight gains. However, about $63 \%$ of the straw production is left in the plots and therefore consumed by other animals using their right to forage. This finding explains why some farmers are tempted to stock part of their straw production in order to cope with possible shortages of fodder at certain times of the year. There are probably improved techniques for preserving millet straw to be tested with agro-pastoralists.

Concerning the place of ligneous plants in the feeding of cattle on rangelands, Ickowicz (1995) argues that only a part of the total biomass evaluated is consumed by animals. This is the accessible part with the criterion of 
evaluation, the height and the penetrability: it is the useful volume. For this author, a woody forage is characterized by the volume of its accessible part (penetrability), that is to say the periphery of the crown less than $1.5 \mathrm{~m}$. It is therefore this volume that must be taken into account (FAO, 1997). Thus, we notice that woody penetration decreases for cattle that are more attracted to annual grasses. Indeed, the thorny species are very difficult to exploit by cattle because of their morphology (lips wide enough to apprehend small leaves often bipinnate and protected by long spines). Small ruminants, on the other hand, are better able to exploit woody plants. They represent $90 \%$ of the goat diet, $70 \%$ of that of sheep and only $35 \%$ of the cattle diet (Guérin et al., 1987). They constitute a food potential available throughout the year for ruminants (Fall, 1993) and represent more than $35 \%$ of the total biomass on natural pastures (Breman and Ridder, 1991) Resistance to drought and bush fires, coupled with good regeneration capacity, allow them to keep their freshness throughout the year. Woody plants also have the advantage of producing fruits (pods) that increase the total digestibility of the diet (Fall et al., 1997). Woody trees play a decisive role in feeding ruminants, but in the face of overgrazing, which can be a cause of degradation of pastoral areas, better use of crop residues can reduce the effects of pressure on trees.

\section{Conclusion:-}

In conclusion, it can be noted that this study has made it possible to elucidate the real role that ligneous plants play in the feeding of cattle in a system associating the cultivation of the millet with the rearing of cattle and the agropastoral farm. Animals monitored on pasture for one year, allowed reconstitution of the main bolus consisting of herbaceous (41\%), ligneous (34\%), millet straw (21\%) and debris (3\%).

The average annual intake is $4.87 \pm 0.96 \mathrm{Kg} . \mathrm{DM} / \mathrm{UBT} /$ day, falling at the end of the dry season to stabilize at 4.2 Kg.DM/UBT/day. During this period, crop residues (especially millet straw) and woody shrubs that still retain their freshness are the main food resources available for stray animals. There are 28 identified woody species and 23 are considered to be fodder $(82.14 \%)$. Of the $82.14 \%$ of species inventoried as fodder, $43.47 \%$ are very palatable, $17.39 \%$ are palatable and 39.13 are unpalatable. The presence of woody species in natural rangelands and crop residues stored in the open fields, distributed in the right season, guarantees the survival of animals in extensive raiding systems in the face of overgrazing.

\section{Bibliography:-}

1. Ayantunde A.A., Fernandez-Rivera S., Hiernaux P., van Keulen H., Udo H.M.J., Chanono M., 2001. Animal Science, 72, 117-128

2. Blanchard, M., 2010. Gestion de la fertilité des sols et rôle du troupeau dans les systèmes coton-céréalesélevage au Mali-sud. Savoirs techniques locaux et pratiques d'intégration agriculture-élevage, 301.

3. Bognounou F., 2004, Caractérisation et gestion de ligneux fourragers dans les systèmes de production agropastorale du terroir de Dankana en zone Sud soudanienne du Burkina Faso Mémoire de DEA, Université de Ouagadougou, Burkina, 92 pages.

4. Breman et De Ridder, 1991. Manuel sur les pâturages des pays sahéliens. Karthala - ACCT - CTA - Paris.

5. Dione, M., Diop, O., Dieye, P. N., \& Ndao, B., 2008. Le Bassin arachidier. In Caractérisation et typologie des exploitations agricoles familiales du Sénégal: cas du Bassin arachidier (Vol. 8, 31pp). Dakar, Sénégal: ISRA.

6. Diop A.T., Touré O., Ickowicz A., et Diouf A., 2005. Les ressources sylvopastorales In ISRA, ITA, \& CIRAD, Bilan de la recherche agricole et agroalimentaire au Sénégal (91-105pp.). Sénégal.

7. Fall S. T., Traore E. H., Ndiaye K., Ndiaye N. S., Seye B. M., 1997. Utilisation des fruits de Faidherbia albida pour l'alimentation des bovins d'embouche paysanne dans le bassin arachidier au Sénégal, ISRA-LNERV Vol 9 $\mathrm{N}^{\circ} 5$ Novembre 1997.

8. Fall S. T., 1993. Valeur nutritive des fourrages ligneux, leur rôle dans la complémentation des fourrages pauvres des milieux tropicaux, Thèse doct. en Zootec. ENSAA Montpellier 139p.

9. Guérin, H., Friot, D., Mbaye, N., Fall, S. T., Richard, D., Diop, M., et Richard, D., 1987. L’ingestion des fourrages des parcours naturels en zone sahelienne : mesures en stabulation et au paturage.

10. Guérin H., Friot D., Mbaye Nd., 1984. Méthodologie d'étude de la valeur alimentaire des parcours naturels à faible productivité : 1'Approche bibliographique, LNERV, 1983, $\mathrm{n}^{\circ} 103,31 \mathrm{pp}$; et Protocoles et premiers résultats. LNERV, 1984, n $12,33 \mathrm{pp}$.

11. Ickowicz A., Usengumurenyi J., Richard D., Colleie F., et Dupressoir D., 1999. Atelier jachère et systèmes agraires (Ed. Floret, C., Pontanier, R.), 124-138pp. Niamey (Niger)

12. Ickowicz A., 1995. Approche dynamique du bilan fourrager appliquée à des formations pastorales du Sahel tchadien, Thèse de doctorat de l'Université de Paris XII, UFR de Sciences, Spécialité Sciences de la vie et de la 
Santé, 472p.

13. Lericollais, A., 1999. Paysans sereer : dynamiques agraires et mobilités au Sénégal. (M. Eldin \& P. Milleville, Eds.) (Edition IR). Paris: Collection à travers champs.

14. Mbengue, M. (2015). Diversité de gestion et d'efficience des nutriments dans les systèmes de culture du mil (Pennisetum glaucum (L) R . Br .) pratiqués dans une région du bassin arachidier (Diohine). Ecole Nationale Supérieure d'Agriculture (ENSA), Thiès, Sénégal.

15. Traore E., Camara M., Ngom S., Sall C., Boye C. M. et Diarra A. R., 2016. Note on available feed for livestock in eastern Senegal and upper Senegal river basin. Int. J. Adv. Res. 4(8), 2123-2128.

16. Sarr O., Diatta S., Gueye M., Ndiaye P.M., GuissE A., Akpo L.E., 2013. Importance des ligneux fourragers dans un système agropastoral au Sénégal (Afrique de l'ouest) Revue Méd. Vét., 164- 1, 2-8. 